\title{
PENGARUH COMMUNAL ACTIVATION UNTUK MEMBENTUK BRAND LOYALTY PRODUK MINUMAN
}

\author{
Hartiwi Prabowo; Brian Garda Muchardie; Dedy Handrimurtjahjo \\ Jurusan Manajemen, Fakultas Ekonomi dan Komunikasi, BINUS University \\ Jln. K.H. Syahdan No.9, Palmerah, Jakarta Barat 11480 \\ Hartiwi2200@binus.ac.id; ahandrimurtjahjo@binus.edu
}

\begin{abstract}
Established in 1974, PT Sinar Sosro is the first ready-to-drink tea beverage in bottles in Indonesia and in the world. Teh Botol Sosro market position is the leader in ready to drink tea industry. One of the leading products of PT Sinar Sosro is Teh Botol Sosro glass bottle often called RGB (returnable Glass Bottle). To meet the lovers' needs anywhere they are, the latest innovation from Teh Botol Sosro products is Teh Botol Sosro Less Sugar which was launched on August 20, 2008. As the time passes by, the market condition encourages a change in marketing plan that leads to a decentralized system (horizontal) in which the customer demands the same service from the same brand from any location they are. This era is called the New Wave Marketing (2008), which is still running today. The purpose of this research is to analyze the influence of communal activation of the buying decisions to increase brand loyalty in Teh Botol Sosro Less Sugar product. Data collecting technique is the questionnaire to members of the online community Botol Sosro Less Sugar and interviews, while the data analysis technique using path analysis. Path Analysis Results show there was an impact dan significant between Communal Activation and Buying Decisions, and there was also a positive correlation and significant between Buying Decisions and Brand Loyalty.
\end{abstract}

Keywords: communal activation, buying decisions, brand loyalty

\begin{abstract}
ABSTRAK
Berdiri pada tahun 1974, PT Sinar Sosro merupakan perusahaan minuman teh siap minum dalam kemasan botol yang pertama di Indonesia dan di dunia. Posisi pasar teh botol Sosro adalah sebagai leader di industri teh siap minum. Salah satu produk unggulan PT Sinar Sosro adalah Teh Botol Sosro kemasan botol beling atau sering disebut RGB (Returnable Glass Bottle). Untuk memenuhi kebutuhan pecintanya di manapun berada, inovasi terbaru dari produk Teh Botol Sosro adalah Teh Botol Sosro Less Sugar yang telah diluncurkan pada tanggal 20 Agustus 2008. Seiring berjalan waktu, kondisi pasar mendorong adanya perubahan marketing plan yang mengarah ke sistem desentralisasi (horizontal) di mana customer menuntut layanan yang sama dari brand yang sama dari setiap lokasi mereka berada. Era ini disebut New Wave Marketing (2008) yang mana masih berjalan hingga saat ini. Tujuan peneltian ini menganalisis pengaruh communal activation terhadap keputusan membeli untuk meningkatkan brand loyalty pada produk Teh Botol Sosro Less Sugar. Teknik pengumpulan data dengan kuesioner ke anggota komunitas online Teh Botol Sosro Less Sugar dan wawancara, sedangkan teknik analisis data menggunakan Path analysis. Hasil Path Analysis menunjukkan ada pengaruh dan signifikan antara Communal Activation dan Keputusan Membeli serta ada pula pengaruh yang positif dan signifikan antara Keputusan Membeli dan Brand Loyalty.
\end{abstract}

Kata kunci: communal activation, keputusan membeli, brand loyalty 


\section{PENDAHULUAN}

Ketika tingkat konsumsi suatu produk di dalam negeri mengalami penurunan atau dikonsumsi oleh masyarakat dalam jumlah yang sedikit, maka para pemain di industri produk tersebut akan menyadari bahwa ada yang tidak tepat dalam pelaksanaan taktik pemasaran dan bauran pemasaran yang digunakannya. Salah satu teori marketing yang baru, New Wave Marketing menitikberatkan perlunya baruran pemasaran yang disesuaikan dengan kondisi masyarakat saat ini. Dimana marketing mix berubah menjadi crowd combo. Peranan individual sangat dominan, oleh karena itu cakupan pasar akan lebih luas. Namun, crowd berbeda dengan komunitas. Orang-orang dalam komunitas saling peduli serta memiliki ketertarikan dan nilai yang sama. Sementara itu, crowd merupakan kumpulan individu yang lepas (Kartajaya, 2009,). Dalam bukunya, beliau mengambil contoh ibu-ibu yang sedang arisan di sebuah restoran di salah satu mall terbesar di Jakarta adalah komunitas, sedangkan orang-orang yang sedang jalan-jalan di mall tersebut disebut crowd. Crowd combo ini terdiri dari sejumlah elemen, yaitu: co-creation, currency, communal activation dan conversation.

Communal Activation sebagai elemen ketiga dari marketing mix adalah place atau sering dikenal dengan marketing channel. Saluran distribusi inilah yang berperan dalam menghantarkan produk dari produsen ke pelanggan. Praktik channeling di dunia yang serba horizontal ini akan semakin berubah menjadi ke arah komunal, baik itu di online maupun offline. Justru dengan adanya komunitas, perusahaan harus jeli memanfaatkan peluang tersebut untuk memberi nafas hidup pada komunitas yang menguntungkan.

Lalu bagaimana pengaruh communal activation dalam membentuk brand loyalty pelanggan? Durianto, et.al. (2004), menyatakan bahwa salah satu peranan dan kegunaan merek ialah sebuah merek mampu menciptakan komunikasi interaksi dengan konsumen. Dengan kata lain, semakin kokoh ikon itu berdiri, semakin kokoh pula interaksi antara ikon dengan konsumen sehingga terbentuklah asosiasi merek yang memiliki kualitas dan kuantitas yang kuat di benak konsumen. Lanjut Beliau, brand loyalty termasuk kategori ekuitas merek yang berperan meningkatkan penjualan karena bisa menciptakan loyalitas saluran distribusi (communal activation) bagi konsumen.

Sedangkan menurut Giddens (2002), para konsumen yang loyal dalam sebuah komunitas akan proaktif mengikuti informasi-informasi terbaru yang berkaitan dengan merek tersebut. Tambahnya, bahkan bisa berperan serta sebagai juru bicara dari merek tersebut dan selalu mengembangkan hubungan interaksi dengan merek yang bersangkutan sehingga perusahaan dapat mengurangi biaya promosi produknya.

Marconi (1993) juga menyebutkan hal yang senada, yaitu kenyamanan dan kemudahan untuk memperoleh merek merupakan salah satu faktor yang berpengaruh terhadap loyalitas merek. Situasi saat ini, permintaan pasar telah menyudutkan perusahaan untuk menyediakan produk dalam rangka memudahkan konsumen. Hal ini berarti bahwa terjadi kausalitas antara communal activation dengan brand loyalty. Studi kasus penelitian pada produk minuman teh botol less sugar.

Keberhasilan Teh Botol Sosro merajai pasar teh siap minum di Indonesia sebetulnya sangat wajar, mengingat dialah pelopor minuman teh SMDK pertama di Indonesia dan terbesar di dunia Keberhasilan Teh Sosro menghadang serbuan produk minuman asing dimana pangsa pasar PT Sinar Sosro tahun 2009 mencapai 44,1 persen. Masih di atas Coca Cola Group yang memperoleh pangsa pasar 26,2 persen. Untuk kategori teh siap minum, posisi pasarnya tteh botol Sosro menguasai 52,5 persen.(2009).Inovasi produk baru Teh Botol Sosro adalah Less Sugar. Kegiatan promosi yang telah dilakukan PT Sinar Sosro lewat iklan di media elektronik (produk Teh Botol Sosro Less Sugar difokuskan bagi mereka yang berlatarbelakang penderita diabetes, olahragawan/atlet, dan eksekutif muda)dilakukan untuk memupuk loyalitas dan mengendalikan komunitas tersebut, PT Sinar Sosro 
memanfaatkan konsep pemasaran crowd combo, yang disesuaikan dengan era New Wave saat ini ala Hermawan Kartajaya. Tujuan peneltian ini memberi contoh menganalisis pengaruh communal activation terhadap keputusan membeli untuk meningkatkan brand loyalty pada produk Teh Botol Sosro Less Sugar.

\section{Communal Activation}

Elemen ketiga dari marketing mix adalah place atau sering dikenal dengan marketing channel. Saluran distribusi inilah yang berperan dalam menghantarkan produk dari produsen ke pelanggan. Praktik channeling di dunia yang serba horizontal ini akan semakin berubah menjadi ke arah komunal, baik itu di online maupun offline.

Komunitas adalah kumpulan manusia atau kelompok yang berkumpul dan berdiskusi karena memiliki tujuan atau ketertarikan yang sama dalam suatu bidang tertentu. Berbeda dengan terminologi organisasi yang ketat (strict) khususnya berhubungan dengan adanya tujuan tertentu yang dikejar bersama, komunitas relatif lebih bebas karena masing-masing individu bisa saja memiliki tujuan yang berbeda-beda. Sebuah komunitas itu tinggal di dunia nyata maupun dunia maya. Namun, komunitas maya lebih fleksibel terutama dalam dimensi ruang dan waktu. Siapapun, kapanpun, dan dimanapun kita berada, kita masih bisa tetap aktif bergabung dan berdiskusi dalam komunitas maya (Wahono, 2007). Menurut opini dari seorang pakar bernama Susan Fournier dalam buku connect! bahwa komunitas dapat diraih atau dibentuk dengan tiga cara, seperti pada Gambar 1.

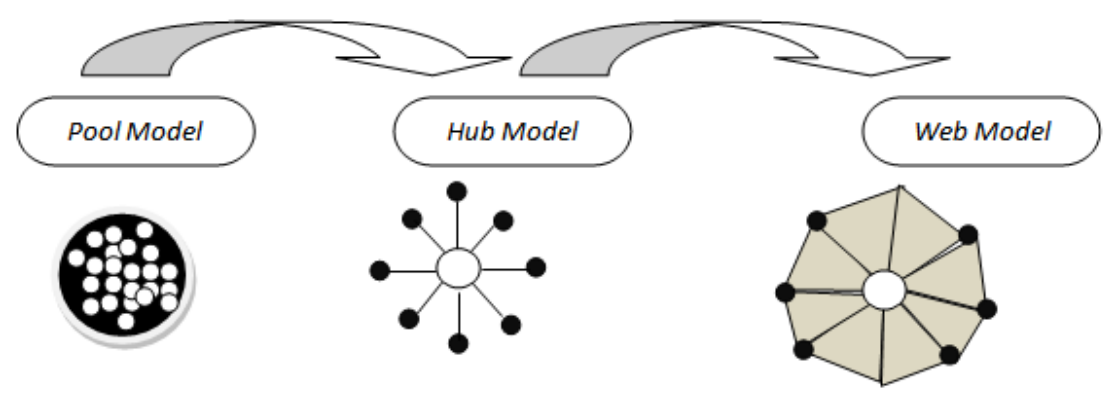

Gambar 1 Tiga Cara Membentuk Komunitas

Sumber: Kartajaya, 2010, p90

Bentuk pool merupakan komunitas paling organik dan natural. Tanpa dibentuk pun, secara otomatis sudah menjadi komunitas tersendiri karena para konsumen punya nilai-nilai, identitas, dan aktivitas yang sama dan tergabung dikarenakan pooling factor yang jelas dan kuat. Contoh konkretnya, komunitas Apple Mac yang terbentuk karena pooling factor-nya jelas, yaitu bersatu melawan Microsoft.

Komunitas berbentuk hubs biasanya bersatu karena kekaguman anggotanya terhadap satu individu. Atau dengan kata lain, keterikatan anggota komunitasnya pada daya magnetik dari ikon bersangkutan sangat kuat. Misalnya komunitas Oprah juga klub-klub sepakbola ternama, seperti AC Milan, Barcelona, Manchester United. Sayangnya, ketika kekuatan (pamor) ikon redup bahkan tidak ada lagi, maka keterikatan tersebut hanya bersifat temporer. Komunitas yang disebut webs ialah bentuk komunitas yang paling kuat dan stabil dimana para anggotanya punya hubungan yang cukup erat satu dengan lainnya. Pada umumnya terjadi secara alamiah di web, seperti facebook, twitter, friendster, dan lain-lain. 
Perusahaan seperti Facebook selaku komunitas jejaring sosial berbasis web merupakan salah satu contoh bagaimana langkah pemasaran yang dilakukan lewat communal activation dapat terwujud. Populasi yang sudah berjumlah kurang lebih 250 juta orang yang difasilitasi dengan berbagai aplikasi dan fitur-fitur yang menunjang kegiatan transaksi secara online.

Saluran distribusi dalam jaman New Wave ini bukan lagi perusahaan distributor atau peritel, namun berupa communal activation yang mampu mengaktifkan sebuah komunitas lewat para pemimpin atau aktivis komunitas tersebut. Dengan kata lain, produsen akan lebih efektif dan efisien apabila berhasil dalam mengelola para aktivis yang lebih paham bahasa komunitas tersebut. Hal ini dikarenakan reputasi dan integritas sebagai pemimpin komunitas menjadi jaminan bagi anggota lainnya. Biaya yang diperlukan untuk mengelola para aktivis ini juga relatif tidak terlalu besar (Kartajaya, 2009).

Maka dari itu, place is communal activation, dimana perusahaan berusaha mengaktifkan komunitasnya lewat connector yang ada di physical (offline) dan virtual (online). Apabila sudah ada connector untuk komunitas, tentunya melakukan aktivitas pemasaran apa saja akan menjadi lebih mudah. Hal ini didukung dari riset yang telah dilakukan Waizly Darwin bahwa adanya keterkaitan antara strategi dan implementasi pemasaran yang new wave dimana strategi yang dimulai dengan communitization atau langkah pemasar dalam melakukan praktik komunitisasi. Aktivitas yang lebih mengerucut lagi yakni, mengeksplorasi dan meninjau lebih dalam komunitas konsumen yang tepat untuk diajak berhubungan secara horizontal dan strategis.

\section{Keputusan Pembelian}

Proses kunci di dalam pembuatan keputusan konsumen ialah proses integrasi dengan mana pengetahuan dikombinasikan untuk mengevaluasi dua atau lebih alternatif perilaku, kemudian pilih salah satu. Hasil dari proses integrasi adalah suatu pilihan, secara kognitif terwakili sebagai intensi perilaku. Intensi perilaku disebut rencana keputusan (Supranto \& Limakrisna, 2007).

Berdasarkan faktor yang dipertimbangkan, menurut Hawkins et al. dalam Simamora (2003), pengambilan keputusan pembelian dapat dibagi menjadi dua, yaitu: (1) pengambilan keputusan berdasarkan atribut produk (atribut based choise), dan (2) pengambilan keputusan berdasarkan sikap (attitude based choise).

Peran keputusan pembelian merupakan hal yang penting bagi pembeli dan penjual (perusahaan) itu sendiri. Terdapat lima peran yang terjadi dalam keputusan membeli yang dijelaskan oleh Simamora (2004) yakni: pemrakarsa (initiator), pemberi pengaruh (influencer), pengambil keputusan (decider), pembeli (buyer), pemakai (user).

Menurut Kotler (2005) ada lima tahap dalam proses pembelian konsumen, yaitu: (1) pengenalan masalah, proses pembelian dimulai saat pembeli mengenali sebuah masalah atau kebutuhan. Kebutuhan tersebut dapat dicetuskan oleh rangsangan internal atau eksternal; (2) pencarian informasi, konsumen yang tergugah kebutuhannya, akan terdorong untuk mencari informasi yang lebih banyak. Tantangan bagi marketer adalah mengenali sumber informasi yang paling berpengaruh; (3) evaluasi alternatif, mengevaluasi berbagai alternatif yang ada dalam konteks kepercayaan utama tentang konsekuensi yang relevan dan mengkombinasikan pengetahuan tersebut untuk membuat keputusan; (4) keputusan pembelian, calon pembeli menentukan apa dan dimana produk pilihan mereka akan dibeli. Marketer harus menyediakan jalan paling mudah bagi calon pembeli untuk mendapatkan produk yang mereka inginkan. Misalnya, produk sudah disalurkan hingga ke pengecerpengecer kecil sekalipun sehingga dapat menjangkau para calon pelanggan; (5) perilaku pasca pembelian, dalam perilaku pasca pembelian, hanya ada tiga kemungkinan, yaitu: performa produk/jasa sama dengan ekspektasi, performa produk/jasa lebih rendah dari ekspektasi, atau performa produk/jasa lebih tinggi dari ekspektasi. 


\section{Brand Loyalty}

Brand loyalty adalah pilihan yang dilakukan konsumen untuk membeli merek tertentu dibandingkan merek yang lain dalam satu kategori produk (Giddens, 2002). Menurut Diosi Budi Utama (2007), brand loyalty juga merupakan suatu pengukuran derajat di mana konsumen, mengakui suatu merek, yang dihasilkan dari kepuasan yang berkelanjutan dan adanya peningkatan dalam pembelian kembali suatu produk 30 dengan sedikit pemikiran namun dengan keterlibatan yang tinggi. Brand loyalty terikat dengan laba masa depan, karena secara langsung dihubungkan dengan tingkat penjualan di masa depan. Pelanggan yang setia menunjukkan respon yang lebih menyenangkan terhadap suatu merek dibandingkan dengan pelanggan yang tidak loyal. Pelanggan yang setia terhadap sebuah merek akan melakukan pembelian secara rutin dan menolak untuk mengganti atau menukar dengan merek yang lain (Yoo, et al., 2000).

\section{Tingkatan-Tingkatan Brand Loyalty}

Menurut Durianto, et.al. (2001), tingkatan-tingkatan yang terdapat dalam loyalitas merek adalah: (1) berpindah-pindah (switcher); (2) pembeli yang bersifat kebiasaan (habitual buyer); (3) pembeli yang puas karena biaya peralihan (satisfied buyer); (4) menyukai merek (liking the brand); (5) pembeli yang komit (committed buyer).

Pelanggan yang berada pada tingkat loyalitas berpindah-pindah dikatakan sebagai pelanggan yang berada pada tingkat yang paling dasar. Semakin sering pembelian konsumen berpindah dari suatu merek ke merek yang lain mengindikasikan bahwa mereka tidak loyal, semua merek dianggap memadai. Dalam hal ini, merek memegang peranan kecil dalam keputusan pembelian. Ciri yang jelas dalam kategori ini adalah mereka membeli suatu merek karena harganya murah.

Pembeli pada tingkat yang bersifat kebiasaan dikategorikan sebagai pembeli yang puas dengan merek produk yang dikonsumsinya. Tidak ada alasan yang kuat baginya untuk membeli merek produk lain atau berpindah merek, terutama jika peralihan itu membutuhkan usaha, biaya, atau pengorbanan lain. Dapat disimpulkan bahwa pembeli ini membeli suatu merek karena kebiasaan. Pada tingkatan puas karena biaya peralihan, pembeli merek masuk ke dalam kategori puas bila mereka mengonsumsi merek tersebut.

Pembeli dalam kategori menyukai merek adalah pembeli yang benar-benar menyukai merek tersebut. Pada tingkat ini dijumpai perasaan emosional yang terkait dengan merek. Rasa suka pembeli ini bisa saja didasari oleh asosiasi yang terkait dengan simbol, rangkaian pengalaman dalam penggunaan sebelumnya baik yang dialami pribadi maupun kerabatnya ataupun yang disebabkan oleh karena persepsi kualitas yang tinggi. Pada tahap ini pembeli merupakan pelanggan yang setia. Mereka memiliki suatu kebanggaan sebagai pengguna suatu merek dan bahkan merek tersebut menjadi sangat penting bagi mereka dipandang dari segi fungsinya maupun sebagai suatu ekspresi mengenai siapa mereka sebenarnya. Pada tingkatan ini, salah satu aktualisasi loyalitas pembeli ditujukan oleh tindakan merekomendasikan dan mempromosikan merek tersebut kepada pihak lain.

\section{METODE}

Jenis penelitian yang digunakan adalah penelitian deskriptif asosiatif. Teknik pengumpulan data dengan menggunakan kuesioner ke 107 anggota komunitas online Teh Botol Sosro Less Sugar, dan skala kuesioner adalah skala Likert. Teknik analisis menggunakan beberapa teknik, yaitu Uji Validitas, Uji Reliabilitas, Uji Normalitas dan analisis Jalur. Hipotesis penelitian 


\section{HASIL DAN PEMBAHASAN}

\section{Profil Responden}

Frekuensi responden mengonsumsi Teh Botol Sosro Less Sugar dalam sebulan. Dari 107 anggota komunitas online Teh Botol Sosro Less Sugar, terkumpul data primer sebagai berikut (1) 11 orang (10,28\%) mengonsumsi sebanyak 1 kali,(2) Konsumsi 2 kali sebanyak 14 orang (13,08\%), (3) mayoritas 36 orang $(33,65 \%)$ mengonsumsi secara rutin sebanyak 3 kali. (4) Selanjutnya, 30 orang $(28,04 \%)$ mengonsumsi produk tersebut lebih dari 3 kali dan (5) sisanya 16 orang (14,95\%) jarang atau kadang-kadang (tidak menentu) dalam mengonsumsi produk Teh Botol Sosro Less Sugar. Untuk lebih jelasnya dapat dilihat pada Gambar 2.

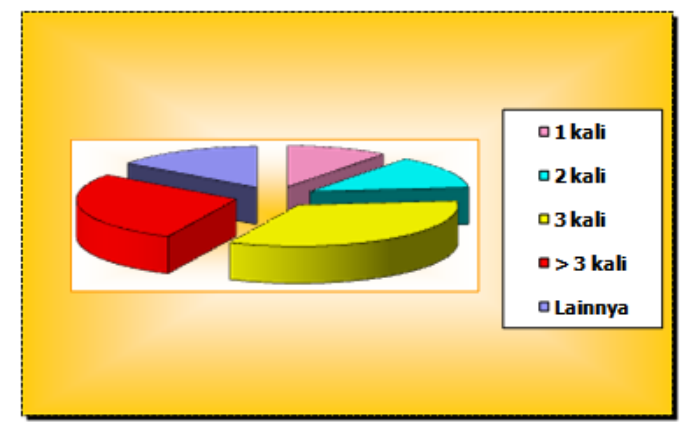

Gambar 2 Profile responden berdasarkan frekuensi responden mengonsumsi Teh Botol Sosro Less Sugar dalam Sebulan

Situs jejaring komunitas online yang sering dikunjungi responden. Pada gambar 3 dapat dilihat beberapa situs jejaring sosial yang biasa dikunjungi oleh para anggota komunitas online Teh Botol Sosro Less Sugar.

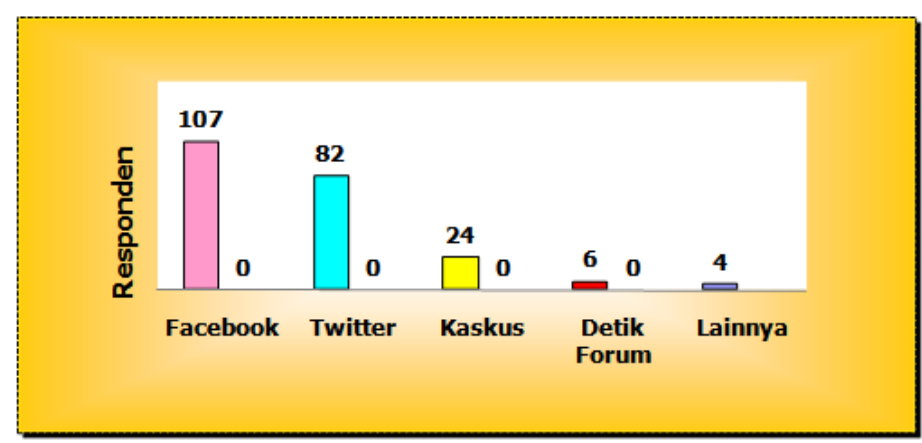

Gambar 3 Profile Responden berdasarkan

Situs Jejaring Komunitas Online yang Sering Dikunjungi

\section{Analisis Pengaruh Communal Activation terhadap Keputusan Membeli pada produk Teh Botol Sosro Less Sugar}

Sebelum melakukan analisis, akan ditampilkan terlebih dahulu struktur hubungan kausal antara variabel Communal Activation (X), Keputusan Membeli (Y), dan Brand Loyalty (Z) dalam Gambar 4. berikut ini: 


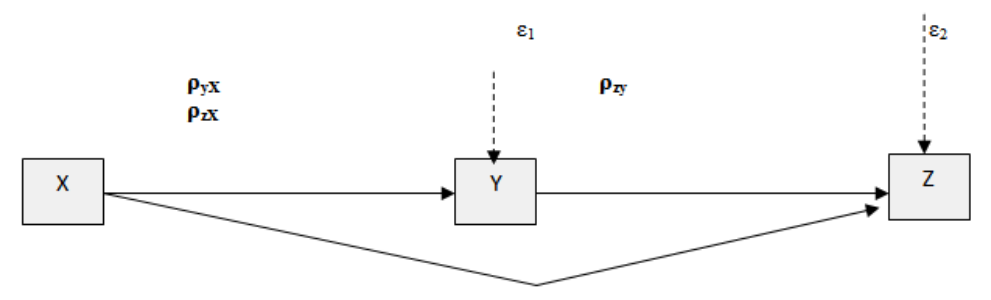

Gambar 4 Struktur hubungan X, Y, dan Z

Untuk melakukan analisa jalur maka Struktur Hubungan pada Gambar 4 akan dibagi menjadi 2 bagian, yaitu sub-struktur 1 dan sub-struktur 2, di mana sub-struktur 1 akan diuraikan dalam sub-bab ini, dan sub-struktur 2 akan diuraikan selanjutnya. Selanjutnya, dengan menggunakan bantuan program SPSS, analisa data X dan Y memperoleh hasil diolah dengan menggunakan program SPSS, sehingga menghasilkan output seperti pada Tabel 1.

Tabel 1 Coefficients Sub-struktur

Coefficients ${ }^{a}$

\begin{tabular}{|c|c|c|c|c|c|c|}
\hline \multirow{2}{*}{\multicolumn{2}{|c|}{ Model }} & \multicolumn{2}{|c|}{$\begin{array}{l}\text { Unstandardized } \\
\text { Coefficients }\end{array}$} & \multirow{2}{*}{$\begin{array}{c}\text { Standardized } \\
\text { Coefficients } \\
\text { Beta }\end{array}$} & \multirow[b]{2}{*}{$\mathrm{t}$} & \multirow[b]{2}{*}{ Sig. } \\
\hline & & $\mathrm{B}$ & Std. Error & & & \\
\hline \multirow[t]{2}{*}{1} & (Constant) & 2,225 &, 289 & & 7,704 &, 000 \\
\hline & Communal_Activation &, 517 &, 082 &, 523 & 6,283 &, 000 \\
\hline
\end{tabular}

a. Dependent Variable: Keputusan_Membeli

Tabel 2 Model Summary Sub-struktur 1

Model Summary

\begin{tabular}{|l|c|c|c|c|}
\hline Model & $\mathrm{R}$ & R Square & $\begin{array}{c}\text { Adjusted R } \\
\text { Square }\end{array}$ & $\begin{array}{c}\text { Std. Error of the } \\
\text { Estimate }\end{array}$ \\
\hline 1 &, $523(\mathrm{a})$ &, 273 &, 266 &, 4428540 \\
\hline
\end{tabular}

Berdasarkan tabel 2, Korelasi Variabel Communal Activation (X) dan Keputusan Membeli (Y) $=0,523$, sehingga hubungan kedua variabel tersebut bersifat cukup kuat dan searah. Kemudian dianalisa sub-struktur 1 dengan menggunakan analisis jalur, dengan persamaan struktural adalah:

$$
\mathrm{Y}=\rho_{\mathrm{yx}} \mathrm{X}+\rho_{\mathrm{y}} \varepsilon_{1}
$$

Hipotesis

Ho : Variabel Communal Activation (X) tidak memiliki kontribusi yang signifikan terhadap variabel Keputusan Membeli (Y) pada produk Teh Botol Sosro Less Sugar

Ha : Variabel Communal Activation (X) memiliki kontribusi yang signifikan terhadap variabel Keputusan Membeli (Y) pada produk Teh Botol Sosro Less Sugar

Dasar Pengambilan Keputusan

Sig $\geq 0,05$ Ho diterima

Sig $<0,05$ Ho ditolak 
Hasil

Sig $=0,000<0,05$ maka Ho ditolak dan Ha diterima

Kesimpulan

Variabel Communal Activation (X) memiliki kontribusi yang signifikan terhadap variabel Keputusan Membeli (Y) pada produk Teh Botol Sosro Less Sugar.

Besarnya pengaruh variabel $\mathrm{X}$ terhadap variabel $\mathrm{Y}$ dapat diketahui dengan melihat nilai Rsquare pada Tabel 2, dimana nilai $\mathrm{R}^{2}=0,273=27,3 \%$. Jadi, 27,3\% nilai dari variabel $\mathrm{Y}$ dipengaruhi oleh variabel $\mathrm{X}$, sedangkan sisanya sebesar $72,7 \%$ dipengaruhi oleh variabel lain di luar penelitian ini. Sementara itu, besarnya koefisien jalur bagi variabel lain di luar penelitian yang mempengaruhi nilai variabel $\mathrm{Y}(\rho \mathrm{Y})=\sqrt{1-R^{2}}=\sqrt{1-0,273}=0,8526$.

Masih mengacu pada Tabel 2, nilai R (koefisien korelasi) diketahui sebesar 0,523. Hal ini berarti hubungan antara variabel bebas $\mathrm{X}$ dengan variabel terikat $\mathrm{Y}$ bersifat kuat (karena nilai $\mathrm{R}$ lebih besar dari 0,5) dan searah (karena nilai $\mathrm{R}$ positif).

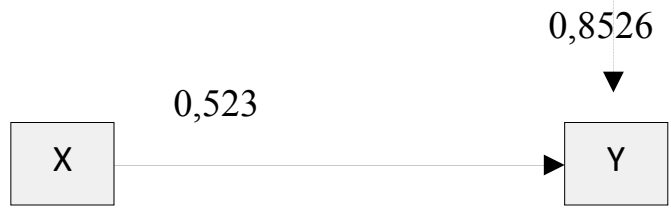

Gambar 5 Sub-struktur 1 beserta koefisien jalur

Jadi dapat diperoleh persamaan stuktural sub-struktur 1:

$\mathrm{Y}=0,523 \mathrm{X}+0,8526 \varepsilon_{1}$ di mana $\mathrm{R}^{2}=0,273$

\section{Analisis Pengaruh Communal Activation dan Keputusan Membeli terhadap Brand Loyalty pada Produk Teh Botol Sosro Less Sugar}

Selanjutnya, analisa pengaruh Communal Activation (X) dan Keputusan Membeli (Y) terhadap Brand Loyalty (Z) akan digambarkan dalam model sub-struktur 2. Kemudian untuk melihat hubungan serta pengaruh $\mathrm{X}$ dan $\mathrm{Y}$ terhadap $\mathrm{Z}$ dapat dibantu dengan menggunakan program SPSS yang menghasilkan output seperti pada Tabel 3.

Tabel 3 Coefficients Sub-struktur 2

\begin{tabular}{|c|c|c|c|c|c|c|}
\hline \multicolumn{7}{|c|}{ Coefficients ${ }^{a}$} \\
\hline \multirow[b]{2}{*}{ Model } & & \multicolumn{2}{|c|}{$\begin{array}{c}\text { Unstandardized } \\
\text { Coefficients }\end{array}$} & \multirow{2}{*}{$\begin{array}{c}\text { Standardized } \\
\text { Coefficients } \\
\text { Beta } \\
\end{array}$} & \multirow[b]{2}{*}{$t$} & \multirow[b]{2}{*}{ Sig. } \\
\hline & & $\mathrm{B}$ & Std. Error & & & \\
\hline & (Constant) & 188 & ,328 & & .575 & ,567 \\
\hline & Communal_Activation &, 589 &, 088 &, 552 & 6,724 &, 000 \\
\hline & Keputusan_Membeli &, 247 &, 088 &, 229 & 2,792 &, 006 \\
\hline
\end{tabular}

a. Dependent Variable: Brand_Loyalty 


\section{Model Summary}

\begin{tabular}{|c|c|c|c|c|}
\hline Model & $\mathrm{R}$ & $\mathrm{R}$ Square & $\begin{array}{c}\text { Adjusted R } \\
\text { Square }\end{array}$ & $\begin{array}{c}\text { Std. Error of } \\
\text { the Estimate }\end{array}$ \\
\hline 1 &, $700(\mathrm{a})$ &, 490 &, 480 &, 4015341 \\
\hline
\end{tabular}

a Predictors: (Constant), Keputusan_Membeli, Communal_Activation

Tabel 5 Sifat Hubungan Bivariat X, Y, dan Z

\begin{tabular}{ccc}
\hline Hubungan antara & Korelasi & Sifat Hubungan \\
\hline X dengan Z & 0,672 & Kuat, Searah, dan Signifikan \\
Y dengan Z & 0,518 & Cukup Kuat, Searah, dan Signifikan \\
\hline
\end{tabular}

Kemudian dianalisa sub-struktur 2 dengan menggunakan analisis jalur, dengan persamaan struktural sebagai berikut: $Z=\rho_{z x} X+\rho_{z y} Y+\rho_{z} \varepsilon_{2}$

\section{Pengujian secara Simultan (Keseluruhan) antar Variabel Bebas $\mathbf{X}$ dan Variabel $Y$ dengan Variabel terikat $Z$}

Hipotesis

Ho : Variabel Communal Activation (X) dan Keputusan Membeli (Y) tidak memiliki kontribusi yang signifikan secara simultan terhadap variabel Brand Loyalty (Z) pada Produk Teh Botol Sosro Less Sugar

Ha : Variabel Communal Activation (X) dan Keputusan Membeli (Y) memiliki kontribusi yang signifikan secara simultan terhadap variabel Brand Loyalty $(\mathrm{Z})$ pada Produk Teh Botol Sosro Less Sugar

Dasar Pengambilan Keputusan

Sig $\geq 0,05$ Ho diterima, Sig $<0,05$ Ho ditolak

Hasil

Sig $=0,000<0,05$ maka Ho ditolak dan Ha diterima

Kesimpulan

Variabel Communal Activation (X) dan Keputusan Membeli (Y) memiliki kontribusi yang signifikan secara simultan terhadap variabel Brand Loyalty (Z) pada Produk Teh Botol Sosro Less Sugar. Maka itu, pengujian secara individual dapat dilakukan atau dilanjutkan.

Besarnya pengaruh variabel $\mathrm{X}$ dan variabel $\mathrm{Y}$ secara simultan terhadap variabel $\mathrm{Z}$ dapat diketahui dengan melihat nilai Rsquare pada Tabel 4. dimana nilai $\mathrm{R}^{2}=0,490=49 \%$. Jadi, $49 \%$ nilai dari variabel $\mathrm{Z}$ dipengaruhi oleh variabel $\mathrm{X}$ dan variabel $\mathrm{Y}$, sedangkan sisanya sebesar $51 \%$ dipengaruhi oleh variabel lain di luar penelitian ini. Sementara itu, besarnya koefisien jalur bagi variabel lain di luar penelitian yang mempengaruhi nilai variabel $\mathrm{Y}(\rho \mathrm{Y})=\sqrt{1-R^{2}}=\sqrt{1-0,490}=$ 0,7141 . 
Nilai R (koefisien korelasi) diketahui sebesar 0,700. Hal ini berarti hubungan antara variabel bebas $\mathrm{X}$ dan $\mathrm{Y}$ secara bersama-sama dengan variabel terikat $\mathrm{Z}$ bersifat kuat (karena nilai $\mathrm{R}$ lebih besar dari 0,5 ) dan searah (karena nilai $\mathrm{R}$ positif).

\section{Pengujian secara Individual antara Variabel X dan Variabel Y terhadap Variabel Z}

Setelah dilakukan uji pengaruh secara simultan, maka dilakukan uji individual, di mana dicari pengaruh masing-masing variabel $\mathrm{X}$ dan variabel $\mathrm{Y}$ terhadap variabel $\mathrm{Z}$ secara individual.

\section{Pengujian secara Individual antara Variabel $X$ terhadap Variabel Z}

Pengujian secara individual dapat dilihat pada table 3.

Hipotesis

Ho : Variabel Communal Activation (X) tidak berkontribusi secara signifikan terhadap variabel Brand Loyalty (Z) pada produk Teh Botol Sosro Less Sugar

Ha : Variabel Communal Activation (X) berkontribusi secara signifikan terhadap variabel Brand Loyalty (Z) pada produk Teh Botol Sosro Less Sugar

Dasar Pengambilan Keputusan

Sig $\geq 0,05$ Ho diterima . Sig $<0,05$ Ho ditolak

Hasil

Sig $=0,000<0,05$ maka Ho ditolak dan Ha diterima

Kesimpulan

Variabel Communal Activation (X) berkontribusi secara signifikan terhadap variabel Brand Loyalty (Z) pada produk Teh Botol Sosro Less Sugar.

\section{Pengujian secara Individual antara Variabel Y terhadap Variabel Z}

Hipotesis

Ho : Variabel Keputusan Membeli (Y) tidak berkontribusi secara signifikan terhadap variabel Brand Loyalty (Z) pada produk Teh Botol Sosro Less Sugar

Ha : Variabel Keputusan Membeli (Y) berkontribusi secara signifikan terhadap variabel Brand Loyalty (Z) pada produk Teh Botol Sosro Less Sugar

Dasar Pengambilan Keputusan

Sig $\geq 0,05$ Ho diterima, Sig $<0,05$ Ho ditolak

Hasil

Sig $=0,006<0,05$ maka Ho ditolak dan Ha diterima

Kesimpulan

Variabel Keputusan Membeli (Y) berkontribusi secara signifikan terhadap variabel Brand Loyalty (Z) pada produk Teh Botol Sosro Less Sugar. $\mathrm{Z}=0,552 \mathrm{X}+0,229 \mathrm{Y}+0,7141 \varepsilon_{2}$ di mana $\mathrm{R}^{2}=0,490$

Jadi keseluruhan pengaruh kausal variabel Communal Activation (X) dan Keputusan Membeli (X) dan dampaknya terhadap Brand Loyalty (Z) dapat digambarkan dalam model struktur lengkap sebagai berikut (Gambar 6). 


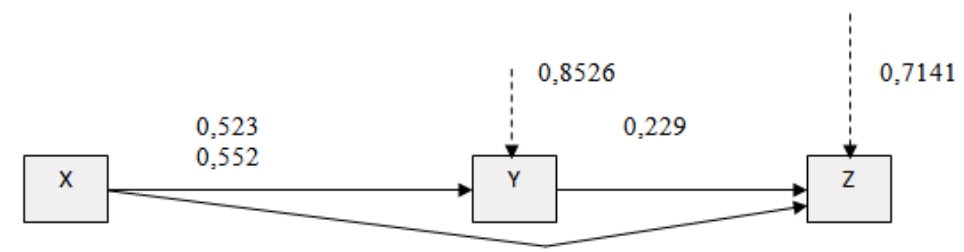

Gambar 6 Hubungan Kausal Empiris Variabel X dan Variabel Y terhadap Variabel Z

Kemudian seluruh koefisien jalur dari hubungan kausal dapat diketahui pengaruh kausal langsung (PKL), pengaruh kausal tidak langsung (PKTL), serta pengaruh kausal total (PKT) dari tiaptiap variabel. Hasilnya dirangkum dalam Tabel 6.

Tabel 6 Rangkuman Hubungan Kausal Empiris Variabel X dan Variabel Y terhadap Variabel Z

\begin{tabular}{cccccc}
\hline Variabel & Koefisien Jalur & Langsung & $\begin{array}{c}\text { Tidak Langsung } \\
\text { Melalui } \mathbf{Y}\end{array}$ & Total & $\begin{array}{c}\text { Pengaruh } \\
\text { Bersama }\end{array}$ \\
\hline $\mathrm{X}$ & 0,552 & 0,552 & 0,229 & 0,678 & - \\
$\mathrm{Y}$ & 0,229 & 0,229 & - & 0,229 & - \\
$\boldsymbol{\varepsilon}_{1}$ & 0,8526 & $0,8526^{2}=0,609$ & - & - & - \\
$\boldsymbol{\varepsilon}_{2}$ & 0,7141 & $0,7141^{2}=0,510$ & - & - & - \\
$\mathrm{X}$ dan $\mathrm{Y}$ & - & - & - & - & 0,490 \\
\hline
\end{tabular}

Berdasarkan Tabel 6, hipotesis pertama: "Ada pengaruh yang positif dan signifikan variabel communal activation terhadap keputusan membeli produk Teh Botol Sosro Less Sugar", menyatakan bahwa secara individual diterima, karena berdasarkan pengujian koefisien jalur sub-struktur 1, koefisien jalur variabel $\mathrm{X}$ terhadap variabel $\mathrm{Y}$ secara statistik adalah signifikan. Besarnya kontribusi communal activation berpengaruh langsung terhadap keputusan membeli sebesar $0,523^{2} \times 100 \%=$ $27,3 \%$ dan sisanya $72,7 \%$ dipengaruhi faktor-faktor lain di luar penelitian ini.

Hipotesis kedua: "Ada pengaruh yang positif dan signifikan variabel communal activation terhadap brand loyalty pada produk Teh Botol Sosro Less Sugar", menyatakan bahwa secara individual diterima, karena berdasarkan pengujian koefisien jalur sub-struktur 2, koefisien jalur variabel X terhadap variabel $\mathrm{Z}$ secara statistik adalah signifikan. Besarnya kontribusi communal activation berpengaruh langsung terhadap brand loyalty sebesar $0,552^{2} \times 100 \%=30,4 \%$ dan sisanya $69,6 \%$ dipengaruhi faktor-faktor lain di luar penelitian ini.

Hipotesis kedua: "Ada pengaruh yang positif dan signifikan variabel keputusan membeli terhadap brand loyalty pada produk Teh Botol Sosro Less Sugar", menyatakan bahwa secara individual diterima, karena berdasarkan pengujian koefisien jalur sub-struktur 2, koefisien jalur variabel $\mathrm{Y}$ terhadap $\mathrm{Z}$ secara statistik adalah signifikan. Besarnya kontribusi keputusan membeli berpengaruh langsung terhadap brand loyalty sebesar $0,229^{2} \times 100 \%=5,2 \%$ dan sisanya $94,8 \%$ dipengaruhi faktor-faktor lain di luar penelitian ini.

Hipotesis kedua: "Ada pengaruh yang positif dan signifikan variabel communal activation dan keputusan membeli secara simultan terhadap brand loyalty pada produk Teh Botol Sosro Less Sugar", bahwa secara keseluruhan menyatakan signifikan. Demikian pula, secara individual semua subvariabel diterima, karena berdasarkan pengujian jalur sub-struktur 2, koefisien jalur X terhadap variabel $\mathrm{Z}$ dan variabel $\mathrm{Y}$ terhadap variabel $\mathrm{Z}$ secara statistik adalah signifikan. Besarnya kontribusi communal activation dan keputusan membeli berpengaruh secara simultan yang langsung mempengaruhi brand loyalty adalah $49 \%$ dan sisanya sebesar $51 \%$ dipengaruhi faktor-faktor lain di luar penelitian ini. 


\section{PENUTUP}

Simpulan penulisan ini adalah: (1) ada pengaruh positif dan signifikan variabel Communal Activation terhadap Keputusan Membeli; (2) Communal Activation berpengaruh positif dan signifikan terhadap Brand Loyalty; (3) keputusan Membeli berpengaruh positif dan signifikan terhadap Brand Loyalty; (4) ada pengaruh positif dan signifikan variabel Communal Activation terhadap Brand Loyalty melalui Keputusan Membeli.

\section{Saran}

Sebaiknya PT Sinar Sosro lebih memfokuskan diri untuk menerapkan crowd combo, terutama elemen communal activation ketimbang elemen lainnya, dimana nantinya akan berdampak otomatis pada conversation yang terjalin di dalam sebuah komunitas dan diharapkan agar perilaku keputusan membeli yang dilakukan anggota komunitas online facebook Teh Botol Sosro Less Sugar akan semakin meningkat. Dikarenakan praktik co-creation terhubung erat dengan currency yang lebih cenderung diimplementasikan pada kategori produk high involvement dimana proses pembeliannya berlangsung lebih lama, sedangkan Teh Botol Sosro Less Sugar termasuk kategori produk low involvement yang prosesnya relatif singkat dan lebih bersifat beli putus. Aktivitas communal activation yang bisa dilakukan adalah mengalokasikan dana promosi lebih diorientasikan untuk mempertahankan keberlangsungan hidup komunitasnya, andaikan saja PT Sinar Sosro mengambil peranan sebagai donatur atau sponsorship dalam berbagai acara seminar atau penyuluhan yang berkaitan erat dengan tren global saat ini, yakni gaya hidup sehat dan juga pada event-event kopi darat (biasa disebut kopdar) lainnya, seperti berolahraga (contoh: senam pagi, gerak jalan, bersepeda) bersama.

Sebaiknya PT Sinar Sosro melakukan aktivasi melalui beragam media virtual (online) yang sudah ada, seperti facebook, twitter, detikforum, koprol, dan lain sebagainya sehingga muncul keterikatan emosional antara para anggota komunitas dengan ikon (merek produk Teh Botol Sosro Less Sugar) juga antar sesama anggota komunitas yang berhubungan secara horizontal. Hal demikian dimaksudkan supaya penggemar Teh Botol Sosro Less Sugar yang haus akan informasi mengenai ikonnya dapat selalu meng-update apa yang sedang atau akan dilakukan perusahaan terhadap merek produk yang mereka cintai. Tak bisa dipungkiri, kegiatan aktivasi secara online juga harus diselimuti dengan mengaktifkan komunitasnya lewat aktivis komunitas tersebut selaku connector yang ada di physical (offline). Bilamana perusahaan sudah mampu merangkul connector untuk komunitas tertentu, tentunya dalam melakukan aktivitas pemasaran apa saja akan lebih mudah sekaligus akan meningkatkan daya beli pelanggan.

Pada tahap awal, sebaiknya PT Sinar Sosro mengidentifikasi terlebih dahulu jaringan komunitas mana yang berpotensial untuk mendukung kegiatan crowd combo pada merek produk Teh Botol Sosro Less Sugar. Setelah itu, menelusuri lebih lanjut siapa di balik layar yang memegang kendali komunitas tersebut. Dan selanjutnya memantau segala macam aktivitas yang sudah dan akan dilakukan oleh para anggota komunitas tersebut. Tiga langkah sederhana di atas ditujukan supaya perusahaan pun mengetahui latar belakang (asal muasal) berdirinya komunitas tersebut dan terletak di fase manakah komunitas itu sedang berjalan. Kemudian diharapkan ada perwakilan perusahaan yang mampu menggaet dan membina hubungan dengan connector yang tergabung dalam komunitas tersebut. Melalui adanya komunitas yang loyal ini, pemasar diberikan kemudahan untuk menjaga serta menjalin keharmonisan hubungan dua arah yang menunjang mereka (para anggota komunitas secara online atau offline) secara aktif ikut serta memberikan aspirasi atau suara perwakilan dalam merancang secara konseptual dan menghasilkan produk-produk yang inovatif sesuai dengan keinginan dan kebutuhan pasar. 
Seiring waktu berjalan, sudah seharusnya PT Sinar Sosro menganalisa dan mengembangkan faktor-faktor lain yang dapat mempengaruhi tingkat keputusan membeli dan brand loyalty pada merek Teh Botol Sosro Less Sugar. Dikarenakan communal activation mempengaruhi keputusan membeli hanya sebesar $27,3 \%$ dimana masih terdapat $72,7 \%$ faktor lain yang mempengaruhi tingkat keputusan membeli. Begitu juga, communal activation dan keputusan membeli mempengaruhi brand loyalty sebesar $49 \%$ sehingga masih terdapat $51 \%$ faktor-faktor lain yang mempengaruhi brand loyalty dimana mungkin salah satunya adalah conversation.

\section{DAFTAR PUSTAKA}

Durianto, D., Sugiarto, \& Sitinjak, T. (2001). Strategi menaklukan pasar melalui riset ekuitas dan perilaku konsumen. Jakarta: Gramedia.

Durianto, D., Sugiarto, \& Budiman. (2004). Brand equity ten strategi memimpin pasar. Jakarta: Gramedia Pustaka Utama.

Giddens, N., \& Hofmann, A. (2002). Brand loyalty. Diakses pada 21 Desember 2009, dari: http://www.extension.iastate.edu/agdm/wholefarm

Kartajaya, H., \& Waizly, D. (2010). Connect! Jakarta: Gramedia Pustaka Utama.

Kartajaya, H. (2009). New wave marketing. Jakarta: Gramedia Pustaka Utama.

Kotler, P. (2005). Manajemen pemasaran. Jakarta: Indeks Kelompok Gramedia.

Limakrisna, N., \& Supranto, J. (2007). Perilaku konsumen dan strategi pemasaran. Jakarta: Mitra Wacana Media.

Marconi, J. (1993). Beyond branding. Chicago: Probus.

Simamora, B. (2003). Panduan riset perilaku konsumen. Jakarta: Gramedia Pustaka Utama.

Simamora, B. (2004). Riset pemasaran. Jakarta: Gramedia Pustaka Utama.

Supranto, J. (2001). Statistik teori dan aplikasi. Jakarta: Erlangga.

Usmara, U. (2008). Pemikiran kreatif pemasaran. Yogyakarta: Amara Books.

Wahono, R. S. (2007). 6 Tahap membangun komunitas maya. Diakses pada 10 Mei 2010, dari: http://romisatriawahono.net/2007/05/10/6-tahap-membangun-komunitas-maya/ 